\title{
Location planning in charity retailing
}

Andrew Alexander*, David Cryer** and Steve Wood*

* The School of Management, University of Surrey, Guildford, Surrey, GU2 7XH

** Helen \& Douglas House, 14A Magdalen Road, Oxford, Oxfordshire, OX4 1RW

Correspondence e-mail: a.alexander@surrey.ac.uk

Andrew Alexander is Reader in Retail Management, David Cryer is Retail and Trading Manager for Helen \& Douglas House, Steve Wood is Lecturer in Retail Management.

This is an author copy of the paper A. Alexander, D. Cryer and S. Wood 'Location Planning in Charity Retailing'. Published in International Journal of Retail \& Distribution Management (2008) Vol. 36 N. 6/7 pp536-550. As such the format may vary from the final published version. 


\title{
Location planning in charity retailing
}

\begin{abstract}
Purpose: This paper seeks to evaluate the particular conditions informing locational decision-making and related network planning in the charity retail sector. Its purpose is to identify both differences and commonalities with related debates that have been focussed very largely on the grocery sector and the superstore format. Its wider purpose is to contribute to the growing literature on charity retailing which has not considered this aspect of retail management in detail.

Approach: Details the particularities of charity retailing locational decision-making and network planning through a detailed case-study consideration of a hospice charity's emerging retail store network.

Findings: Finds that existing conceptual and practical considerations pertaining to locational-decision making in retailing require a nuanced re-revaluation in relation to the locational and network planning of charity retailers. Identifies the importance of supply chain (stock donators) and workforce factors together with the customer demand in informing locational decision making.

Originality/Value: Detailed academic consideration of location planning in the charity shop sector is absent in the literature. The paper addresses this.

Keywords: Charity shops, retail location planning, network planning Paper type: Research Paper
\end{abstract}

\section{Submitted to: International Journal of Retail \& Distribution Management}

\section{Acknowledgements}

We would like to acknowledge the kind support of Pitney Bowes MapInfo in granting permission for the use of the map presented in Figure 1 and CACI for granting permission for the use of the ACORN profiles presented in Figures 3 and 4. 


\section{$\underline{\text { Location planning in charity retailing }}$}

\section{INTRODUCTION}

The announcement in January 2006 of Scope's decision to close 50 shops brought back into sharp focus the competitive conditions faced by many charity retailers. Reports cited poor conditions on the high street and the success of discount clothing chains among the causes for the apparently protracted loss making of some of the charity's shops (MurrayWest, 2006). Yet, alongside such announcements come reports of the planned opening of new specialised charity shops chains, focusing on particular product categories, like Cancer Research UK's Wishes chain, or aimed at perceived market segments such as 'designer label wearers' and 'student groups' (Barnes, 2004; Jardine, 2004; Quilter, 2005).

Rationalisation and roll-out activities like these, and broader discussions of the impact of charity retailing on the high street and commercial property markets, reveal that for the UK charity retail sector, like any other, locational planning and management matters are of considerable importance. Yet, the existing literature on charity shop retailing gives only limited attention to these issues (see for example Broadbridge and Horne, 1994; Horne and Broadbridge, 1995; Parsons, 2002; Horne and Madrell, 2002; Parsons and Broadbridge, 2006). Nonetheless, and as we elaborate below, a close reading of this literature reveals many seemingly unique characteristics of charity store retailing operations. These characteristics have implications for matters of store location and planning and this leads us to consider that there may be distinction between the locational 
imperatives of 'normal' for profit retailers and those of charity retailers. Important questions result from this consideration to which we should give more attention. These include: how is locational planning for new charity stores undertaken? What techniques of locational planning and management are adopted by retailers in the sector? How and to what extent are the drivers of store location in the charity sector similar to those in other sectors?

The significance of these questions becomes more apparent when one considers that there are more than 7000 charity shops trading in the UK (Association of Charity Shops, 2008). Charity Finance's Charity Shops Survey, 2007 surveyed 76 charities comprising 5656 shops. Of these, 29 charities ran chains of ten or fewer shops and one of these had ceased shop operations by its year end. Another 19 charities had between 11 and 24 outlets. Turning to larger chains, 13 charities are reported to have chains of between 25 and 99 shops, with the remainder (14 charities) responsible for chains of 100 shops or more. Oxfam had the most shops, 746 at its 2007 year end. The survey reports charity shop sector profits as $£ 101.4$ million (Charity Shops Survey 2007, p4). Store-based retailing clearly remains a popular strategy for charities. Presence on the high street brings additional benefits to that of retail trading. It provides the public face of many charitable organisations and can visibly promote the charity thus potentially stimulating donations (of stock and cash), legacies, and other forms of income generation.

This paper is divided into four main sections. In the next section we explore the literature on locational decision-making and network planning in order to identify key perspectives 
and to evaluate their relevance to the charity retail sector. In doing so, we seek to reveal what is significant to the effective locational decision-making of charity retailers and where necessary to draw contrasts with the dominant logic drawn from analyses of the grocery trade. This provides a useful starting point for our attempt to answer some of the questions we have posed. In the third section of the paper we present a detailed examination of the retail locational decision-making and planning undertaken by one hospice charity, Helen \& Douglas House (HDH), as it develops its store portfolio. In the final section of the paper we draw together the findings of our literature review and of our case study to highlight key and differentiating factors in charity shop location planning and to briefly outline areas for future research.

\section{LOCATION DECISION MAKING: DEBATES AND THEIR RELEVANCE TO CHARITY RETAILING}

While arguably providing a boost to the academic study of spatial issues concerning retail development, the emergence of the 'new' retail geography since the mid-1990s (Wrigley and Lowe, 1996) has corresponded with less emphasis on matters concerning location forecasting and decision-making. As Birkin et al. (2002) comment, this is a great shame; not least because issues of location planning become relatively more important in retail markets with issues of market saturation, site availability (and ultimately cost) coming to the fore (Bowlby et al., 1984a; Rogers, 2005) - a trend to which the charity retail sector is certainly not immune (Horne and Broadbridge, 1995). 
Historically it is true that the main techniques in store location forecasting and planning have been well discussed in a very broad context (see Davies and Rogers, 1984 for example), while more recent work has continued to underline the importance of technology aiding store forecasting with gravity modelling, neural networks and Geographical Information Systems (GIS) aligned to the more traditional elements of the analogue stores, regression analysis and checklist approaches (Birkin et al., 2002; Mendes and Themido, 2004). However, the degree of appropriateness of these techniques and their usefulness in the charity retail sector has been largely ignored in the literature due to the consistent academic focus on the grocery superstore rather than small retail units across a diversity of retail sectors (e.g. Clarkson et al., 1996; Rogers, 2005)

The recent work that has been produced on location planning has been of three main types - all of which offer limited use in understanding and aiding network planning for charity retailers. First, there has been the continued research and the subsequent publication of highly quantitative work employing intensely technical and computerpowered expertise to the solving of often theoretical location planning issues (e.g. Kuo et al., 2002; Popkowski Leszczyc et al., 2000; Sakashita, 2000; ). This has drawbacks for the application to charity retail forecasting not simply because of its predominant food retail focus but also because the methodologies employed often require very considerable amounts of capital investment in computing infrastructure and associated background data. 
Second, there has been the emergence of a range of largely conceptual research concerning location decision-making that has aided our understanding of the store network expansion process, often contextualising study within the internal decisionmaking infrastructure of the firm (e.g. Bennison et al., 1995; Clarke and Mackaness, 2001; Clarke et al., 1997; 2003; Hernandez et al., 1998). This is interesting and serves to underline how such decision-making is embedded within company structures and individual firm's own asset portfolios while also, in a very practical sense, within the available data and conditions that present themselves. However, to our knowledge this understanding has never been applied to the charity sector.

Thirdly, we have seen a more specialised and growing strand of research that focuses on the availability and the ability to manipulate data sources for use in store location forecasting and decision-making (e.g. Brito and Malerba, 2003; Byrom et al., 2001; Leventhal, 2003; Sleight, 2004). These have useful practical implications across all retail sectors, although not specifically for charity retailing.

There have been a few significant exceptions that have contrasted with the predominant focus on the superstore location forecasting and network planning. Schneider et al (1998) discuss the challenges of store location decision-making within franchise systems. More notably, a recent paper by Pioch and Byrom (2004) on small independent retailer's location decision-making noted that the lack of engagement in the published literature on the location planning of small businesses is mirrored by a lack of expertise in decisionmaking at the level of the firm: 
'The emphasis on the role of location to large retail organisations, including the techniques and methods of site evaluation and the decision-making cultures apparent therein, appears to have been matched by the lack of engagement with the role of location to small independent retailers' (Pioch and Byrom, 2004, p 222).

This emphasises a point recently made by Wood and Browne (2007) in their study of network planning in convenience store retailing where it was noted that smaller retail operators face radically different challenges from the leading large format food retailers that have had the focus of attention in the academic literature. First, smaller operators are fundamentally inferior in terms of the available financial resources to purchase sites but also to dedicate to site evaluation. This leads to many of the high cost datasets and computing infrastructure becoming de facto unavailable, leading to an increased reliance of "rules of thumb" and "intuition" (see also Hernandez and Bennison, 2000; Pioch and Byrom, 2004). Secondly, many of the techniques discussed within the literature are inappropriate at the localised spatial scale of analysis with a restricted catchment and are correspondingly affected by small-scale developments and scheme related issues that necessitate site visits by analysts to appraise their importance (Wood and Tasker, 2008). Accordingly, many of the datasets used by the larger food operators, whether they are sourced from Government data, such as the Census, or from commercial information providers, may lack the necessary rigour for application at the micro spatial scale where the majority of charity retailers operate.

In addition to these already identified issues, charity retailers also face some unique challenges that, to our knowledge, have never been considered in site evaluation research. 
While traditional store network planning places consumers at the forefront of the location decision (Bowlby et al., 1984b), it is important to consider that charity retailing largely relies on a predominantly unpaid workforce - even withstanding the increasing professionalisation of the sector (Broadbridge and Parsons, 2003; Parsons, 2004). Indeed, work by Broadbridge and Horne (1994) has underlined the extent to which charity retail workers live disproportionately closer to the store than conventional shop workers. Furthermore, the charity store clearly lacks a conventional supply chain; instead relying heavily on customer donations of merchandise which are themselves influenced by store location issues. As Hibbert et al. (2005) noted, charity retailers are 'in competition' for second hand stock yet 'donations declined with the advent of the pedestrianisation of High Streets in the mid-1980s' (p 820).

Whilst the extent of these challenges might vary between different types of charitable enterprises (see Parsons, 2004 on the particular relationship that hospice charity shops can develop with their locale), it is clear that the elements of the geography of workforce residence and the geography of customer donations must affect the site location decisionmaking of all charities and have to be considered in tandem with conventional site research issues of catchment analysis that include population, accessibility, standard of high street, retailer-mix - to name only a few.

\section{CASE STUDY: LOCATIONAL DECISION-MAKING AND THE HELEN \& DOUGLAS RETAIL OPERATION.}


Helen House was the world's first children's hospice, opening in Oxford, England in November 1982. The charity expanded its activities in ensuing years, most notably in 2004 when Douglas House was opened on the hospice's existing site in order to provide additional care for young adults aged 16 to $40 .{ }^{[i]}$ The increasing level of activities of Helen \& Douglas House (hereafter HDH) has meant a growing need for capital which led ultimately to more emphasis being placed on charity store retail operations, alongside other initiatives. In $2005 \mathrm{HDH}$ set out upon a strategy to develop a chain of charity shops, building upon one existing unit that was bequeathed to the charity in 2003, but that was of itself very different to conventional charity shops with its appeal being more akin to that of a gift shop. In support of the strategy HDH dedicated a 0.5 FTE management role to location planning and strategy work for its charity shop operation.

One consequence of HDH's comparatively belated turn to charity shop development HDH entered a fairly mature charity shop market. In a number of established retail locations in the charity's core catchment area there were already well-established 'competitors', highlighting the importance of effective locational planning, as well as strong merchandising and other operational disciplines.

As a first step in the process of establishing a larger retail shop network, staff at HDH identified the charity's catchment area. This was done through spatial analysis and mapping of postcode data relating to the charity's existing supporters. The core catchment area of the charity as a whole was determined to be within a 45 minute drive time of $\mathrm{HDH}$ and comprising an area around Oxford itself and encompassing large parts 
of the Thames Valley, the Chilterns and Cotswolds areas. Postcode profiling of the existing supporters registered on the charity's database showed an expected overrepresentation of 'young families' compared with the national average (Index 181), and also an over-representation of 'families with dependent children' (Index 126) - see

\section{Figure 1.}

*** Figure 1 Here $1 * * *$

\section{Initial 'market town' developments: Abingdon and Wantage}

Determination of the charity's core catchment area as a whole enabled meaningful identification of, and search for, potential retail shop locations. This began with a search for suitable market town locations. In the case of these initial developments the identification and search process was basic, driven primarily by a consideration of expected customer demand for the store's outputs. This was estimated based upon the strength of representation in town catchment areas of the two segments of 'young families' and 'families with dependent children'. The town in closest proximity to Oxford that exhibited the required profile was Abingdon, Oxfordshire.

Given its profile and proximity to the charity's Oxford base, thus easing the transfer of stock and personnel between outlets, Abingdon was provisionally identified as the first town to be targeted for a 'full-line' Helen \& Douglas charity shop. Being 'full-line' required a unit to accommodate the full range of Helen \& Douglas charity shop merchandise - ladieswear, menswear, childrenswear, bric-a-brac, books/ videos, small 
electricals etcetera. A shop unit with a sales floor of circa 800 sq. $\mathrm{ft}$. and space for sorting and storage of 700sq. ft. was deemed necessary. Rental levels for prime pitch in Abingdon (on the pedestrianised Bury St) were considered unaffordable on the basis of expected sales potential and other known operating costs. Footfall analysis in various parts of the town revealed a pattern of sustained high pedestrian traffic stretching off prime pitch and between the town's two main car parks. Footfall on High Street was measured by HDH staff at 1500 per hour (see Figure 2). A suitably sized unit, with return frontage, became available along this higher footfall track (High Street) at terms less than half those calculated for a similar unit on prime pitch. The shop was opened in October 2005. At the time of writing it continues to achieve both its sales and profit targets.

*** Figure 2 Here***

A combination of high representation of 'young families' and 'families with dependent children' and the issue of closeness to Oxford again informed the choice of location for the second full-line Helen \& Douglas charity shop at Wantage, Oxfordshire. Wantage had a broadly similar demographic profile to that of Abingdon, albeit with a smaller population size. However, the nature of retailing in Wantage differed significantly from Abingdon, in that areas away from prime pitch (around the town's Market Square) were shown to experience a significant drop off in footfall. Pedestrian flows in the Market Square area were measured at around 2000 per hour compared to 300 per hour on secondary and tertiary streets. Consequently, the approach taken in Abingdon, of 
identifying high footfall secondary areas was not an option in Wantage. As in Abingdon, prime pitch rental levels represented a challenge given required profit levels and expected trading performance. The need to be prime pitch saw HDH switch search emphasis here. Retailing 'full-line' at Abingdon suggested possible compromises based around unit configuration. Units with narrower retail frontages but widening towards the back of the shop and with ancillary space located on an upper floor (or basement) were identified as possible targets. In the UK retail property market such narrower frontages result in smaller amount of higher rented 'Zone A' space, while upper floor and basement ancillary space is charged at the lowest - 'Zone C' - rental cost.

A unit was identified on prime pitch which met these requirements. It had 800sq. ft. of sales space on the ground floor, with a $14 \mathrm{ft}$. frontage, widening to $18 \mathrm{ft}$ at the back, as well as 900 sq. ft. of kitchen/storage space on the first floor. The shop was opened in April 2006 and at the time of writing it is achieving sales and profit targets.

\section{Second stage development: suburban Oxford}

\section{$\underline{\text { Refining Locational Decision-Making: Profiling Key Groups }}$}

Clearly, the suburbs of Oxford also presented a strong opportunity for the location of Helen \& Douglas charity shops. However, despite the success of Abingdon and Wantage, there was a concern that the demographic profiling that had been used to date had been based only on a broad analysis of what constituted a HDH 'supporter'. This was deemed sufficient when targeting market towns, but an improved methodology was required in order to understand the dynamics of urban areas, such as Oxford, where potential 
catchment areas were perceived to be smaller and more homogenous than those of typical market towns. The foundation for the more refined locational decision-making in this situation was the demographic profiling of three key groups vital to the success of any charity shop, viz. customers, stock donators and volunteers.

Customers: Charity shop customers are diverse. Some customers come from some of the lower socio-economic groups and use charity shops as 'thrift' shops. However, a significant proportion derives from the more affluent households that include charity shops as a part of their shopping repertoire. An analysis by CACI, using their ACORN classification system, confirms this customer profile. It highlights that three of the key target markets are those households defined as 'Urban Prosperity' 'Comfortably Off' and 'Moderate Means' (see Figure 3).

***Figure 3 Here $* * *$

Donors: Compared to shop customers, with regard to stock donation very affluent households, the co-called 'Wealthy Achievers' are proportionately more important (see Figure 4). An additional significant factor here is the quality of donated stock, rather than just the quantity of stock.

\footnotetext{
*** Figure 4 Here***
} 
Volunteers: This third group is the one about which least is known (there is no CACI analysis available for this category). Experience suggests this group to be socially diverse. People volunteer in charity shops for a wide variety of reasons, from young people keen to get work experience, some pensioners looking to get out and make new acquaintances, through to people looking to help a particular charity or do something worthwhile for their community.

In order to understand people's motivations for volunteering to work for HDH's retailing operations in particular, an analysis was undertaken by the charity of the current group of shop volunteers. Volunteers were categorised into one of the standard socio-economic groupings with an assessment made on the basis of information already known about them. The results from the Social Profile classifications are presented in Table 1. The data show a significant skew towards the $\mathrm{AB}$ social grouping. In total, the $\mathrm{AB}$ classification accounts for half of all Helen \& Douglas shop volunteers, but they make up only just over a quarter of the UK population.

***Table 1 Here***

\section{Choosing the target location:}

Given the above, a two stage approach was undertaken to identify locations for shop opening in suburban Oxford. First, each suburb highlighted on the map (Figure 5) was then assessed as to its retail strength (and potential charity shop location) using a retail ranking/weighted checklist analysis (Nelson, 1958). This was constructed using a simple scoring system, where the total number of shops in a particular location was given the 
highest weighting, with the second highest weighting going to the presence of existing charity shops. The presence of existing charity shops is widely regarded by operators to be a signal of the potential of a location (see also Parsons, 2002, p 591). Other factors scored included the presence (or absence) of multiples and convenience stores, as well as the car parking provision in the area. Second, the city's housing stock was divided into 3 categories (detached, semi-detached etc.) and then further segmented into either public rented or private residential categories. This data was mapped to produce a 'Housing Type' map (see Figure 5). Locations that scored highly on the 'Charity Shop Retail Rankings' list were identified on the map showing housing type as potential target locations. Primary catchment areas were then constructed around each of these locations and generally based upon a one mile radius - each was a bespoke, hand-drawn non-linear catchment area accounting for the boundary effects of roads, rail lines etcetera.

Once these individual catchments had been established, the socio-economic profile of each of the postcodes within the catchment area was derived from Office for National Statistics data. These were aggregated up to give a profile of the catchment area. Those catchment areas that had representation across all of the socio-economic types, but with a skew towards the more affluent groupings (to ensure a good supply of customers, stock donators and volunteers) were defined as the optimum locations and scored highest. Catchment areas that contained predominantly only one, lower socio-economic group scored lowest. The combined scores of the retail ranking analysis and the catchment area analysis determined the overall priority order. For example, an area such as Headington ranks high on the priority list. It has a well-established retail centre and also has a 
catchment area with a suitable cross-section of housing stock, both in the private and public sectors. Conversely, Kennington is a suburb with a good mixture of different housing stock, but almost all of it is in the private sector. More significantly, it does not have an established retail centre and therefore scores low on the list.

The top four areas on the priority list are Summertown, Cowley, Headington and Cowley Road (the linear retail area between Cowley and the City Centre). A shop is currently being developed by Helen \& Douglas on the Cowley Road, and sites are also being actively sought in the other three locations.

*** Figure 5 Here******

\section{CONCLUSION}

The core focus of this paper has been to illustrate the locational decision-making and related network planning of a hospice charity retailer and to make comparison to such practices by 'conventional retailers'. Traditionally, the decision of where to site a retail store has been almost exclusively focused in relation to the potential customer base and key competition. Indeed, this is the basis of the one of the cornerstones of retail location analysis - gravity modelling (Rogers, 1984; for recent developments of this technique see Birkin et al., 2002). However, this case study has underlined that while much of the data analysed and techniques used remain the same (such as using a checklist or "scoring" locations against agreed criteria), some issues are more complex and nuanced in charity retailing. Moreover, systems and data availability for this market is considerably less 
developed while the budget to support such investment decisions could render this impracticable.

Charity stores share some characteristics of convenience stores in the need to study the dynamics of the catchment at a very local and micro spatial scale (Wood and Browne, 2007). The agglomeration of charity stores can positively affect the dynamics of footfall and "perceived quality" of a location. As Parsons (2002, p 591) notes, 'It is not unusual for customers to visit every charity shop on a street'.

The case study has further underlined the extent to which decisions are not only constrained by the availability of sites, or the restricted budget for store development, but also additional factors that are beyond the concern of conventional retailers. While there is an increasing professionalism of the charity sector as management practices are transferred to the non-profit market (Broadbridge and Parsons, 2003), this is not always possible. In particular, two additional concerns are at the forefront of the location decision-making process relating to Helen \& Douglas charity shops.

\section{The supply chain and store location}

Despite observations of the strategic significance of the close relationship between retail units and associated distribution facilities (for example Laulajainen, 1987), the supply chain has rarely been a central consideration in conventional retail location decisionmaking. The supply chain of stock for charity stores is fundamentally different from conventional retailing. In common with most charities, Helen \& Douglas is dependent on 
donations, principally of clothing (Horne and Broadbridge, 1995). Furthermore, it is also in competition with other charity stores and disposal routes to intercept such donations (Hibbert et al., 2005). Location is crucial here. Given the low value of the merchandise, it is often prohibitively expensive to transport stock between branches. Hence, the geography of public donations is a variable that, while troublesome to understand, is essential to consider in the location decision. Indeed, Helen \& Douglas explicitly consider this as they eliminate locations from a choice set, as in the Oxford case.

\section{The workforce and store location}

Concerns over store location in relation to the workforce has rarely been analysed within the retail literature. However, Freathy and O'Connell (2003) note difficulties in recruitment and staff retention in airport retailing and therefore retailers operating in such a locale becoming opportunistic, tending to 'recruit whatever staff were available in the local environs' ( $\mathrm{p}$ 127). More progressive employers are noted as aiding employees by offering subsidised travel tickets. Meanwhile, work by Dawson et al. (1988) found that out-of-town stores drew from a 'structurally and spatially different labour market' to traditional in-town units ( $\mathrm{p} 44)$.

While slight geographical mismatches between the location of residences of the workforce and the place of work in conventional retail are rarely significant, this issue is more problematic in the case of charity retailing as the workforce is principally made up of volunteers. In particular, it is important to note that research has found that volunteers are not especially mobile. One survey found that $60 \%$ of shop volunteers live less than 
two miles from the store, with less than $40 \%$ driving to the shop (Broadbridge and Horne, 1994, p 431). Clearly then, the balancing of an accessible location for consumers has to be weighed up against proximity to the equally essential volunteer base. Accordingly, Helen \& Douglas consider this in its scoring system of assessing potential locations.

\section{Future research directions}

To the best of our knowledge, this is the first academic research into store location decision-making in the charity retail market. We have found that the considerations analysts need to make in this market are markedly different from conventional retailing, notably in the additional consideration of proximity to volunteers, who are unlikely to be highly mobile, and donators, who provide all or very much of the product sold in the shops. There is significant potential to further explore these interesting issues and to deepen our understanding, especially regarding how important these factors are between different charity formats as well as the methodologies employed to actively appraise them.

\section{NOTES}

${ }^{1}$ Helen House was established to provide occasional respite care modelled on that provided in the family home. In any one year, Helen \& Douglas House now provide professional care and support to around 250 children and young adults, as well as their families. 


\section{Tables and Figures}

Figure 1: Map of Helen \& Douglas supporters and estimated core area of support

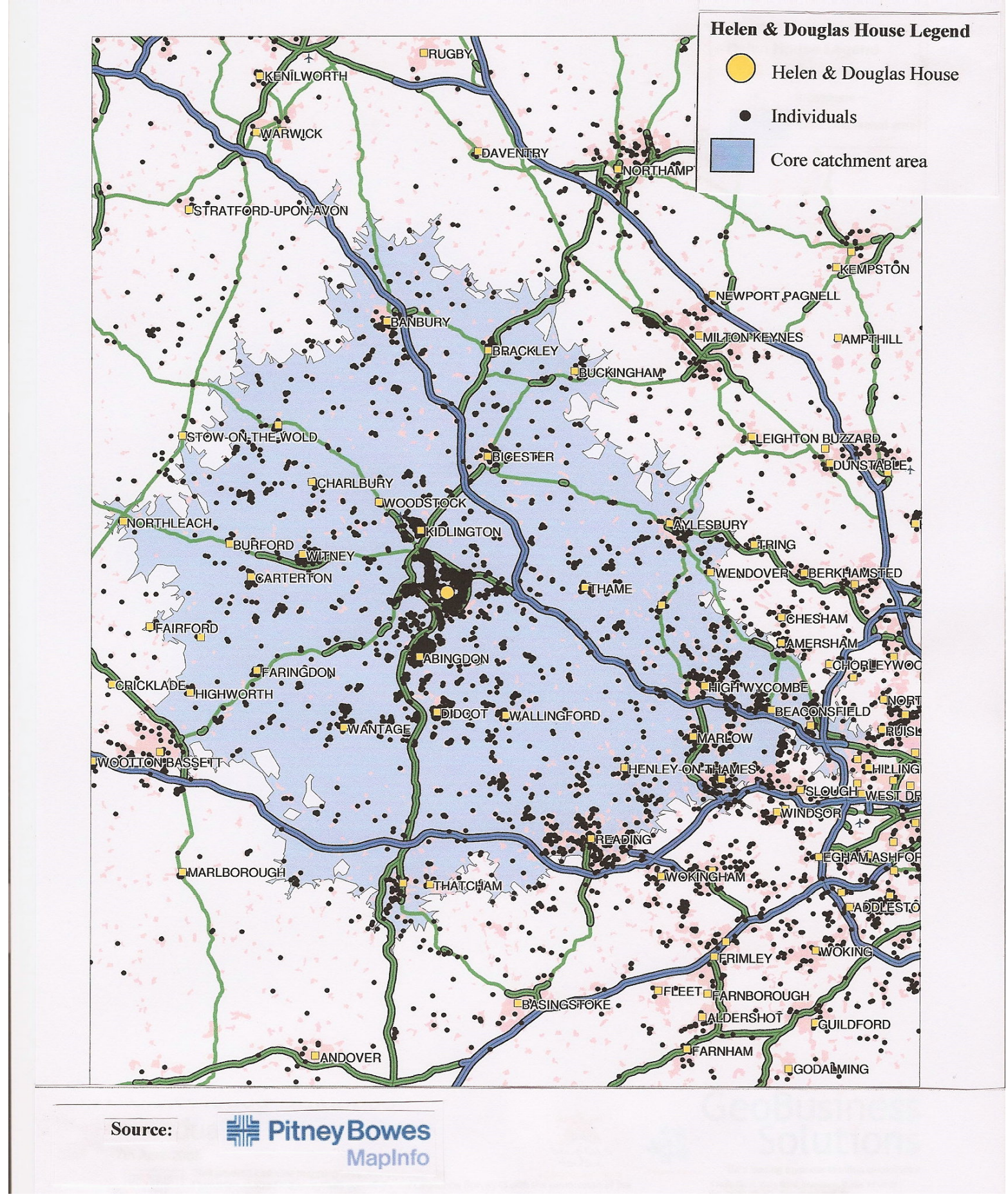


Figure 2: GOAD plan of Abingdon showing Helen \& Douglas store location and summary footfall data (footfall measured by Helen \& Douglas House staff).

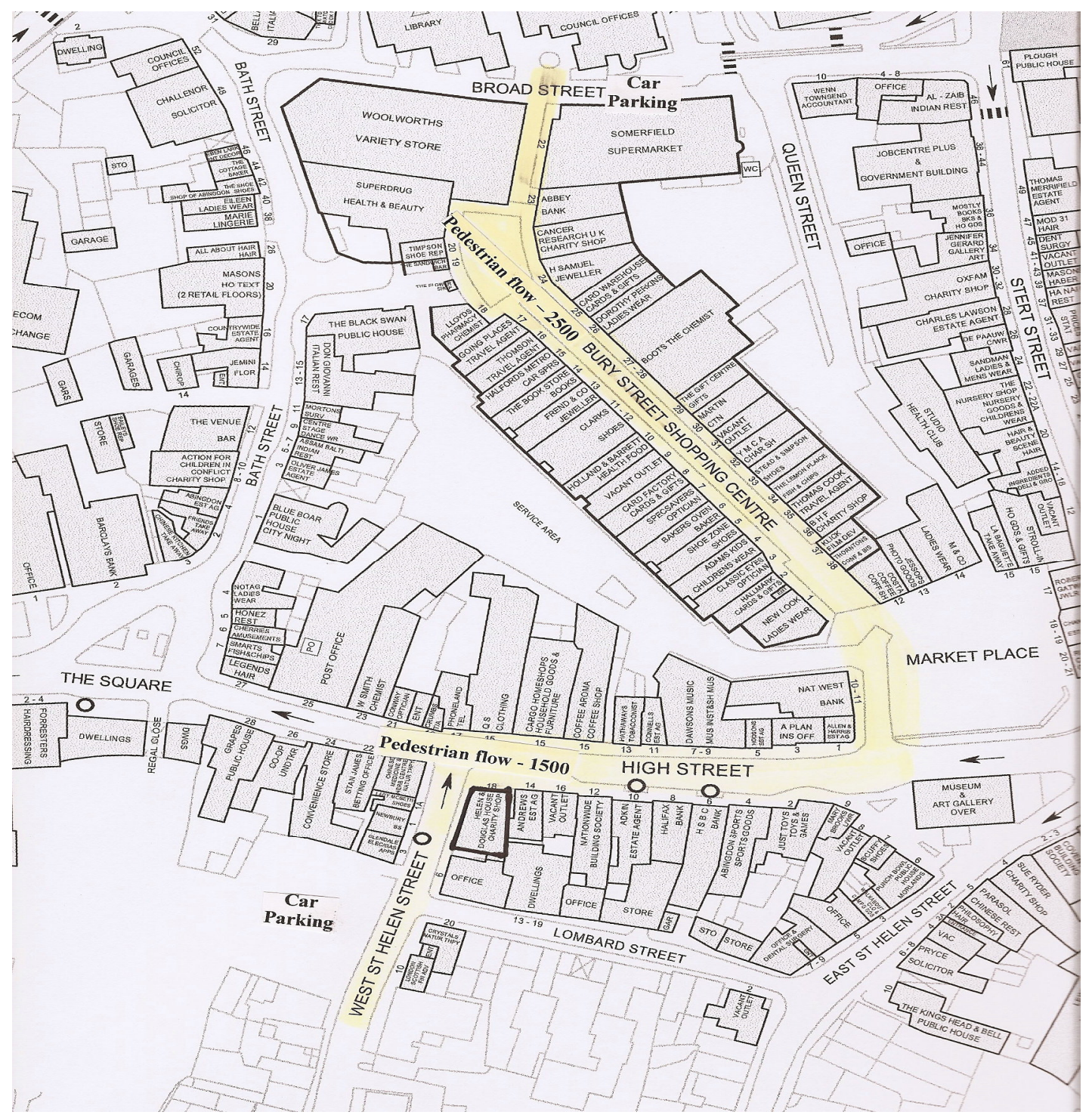


Figure 3: ACORN Category profile of shop customers

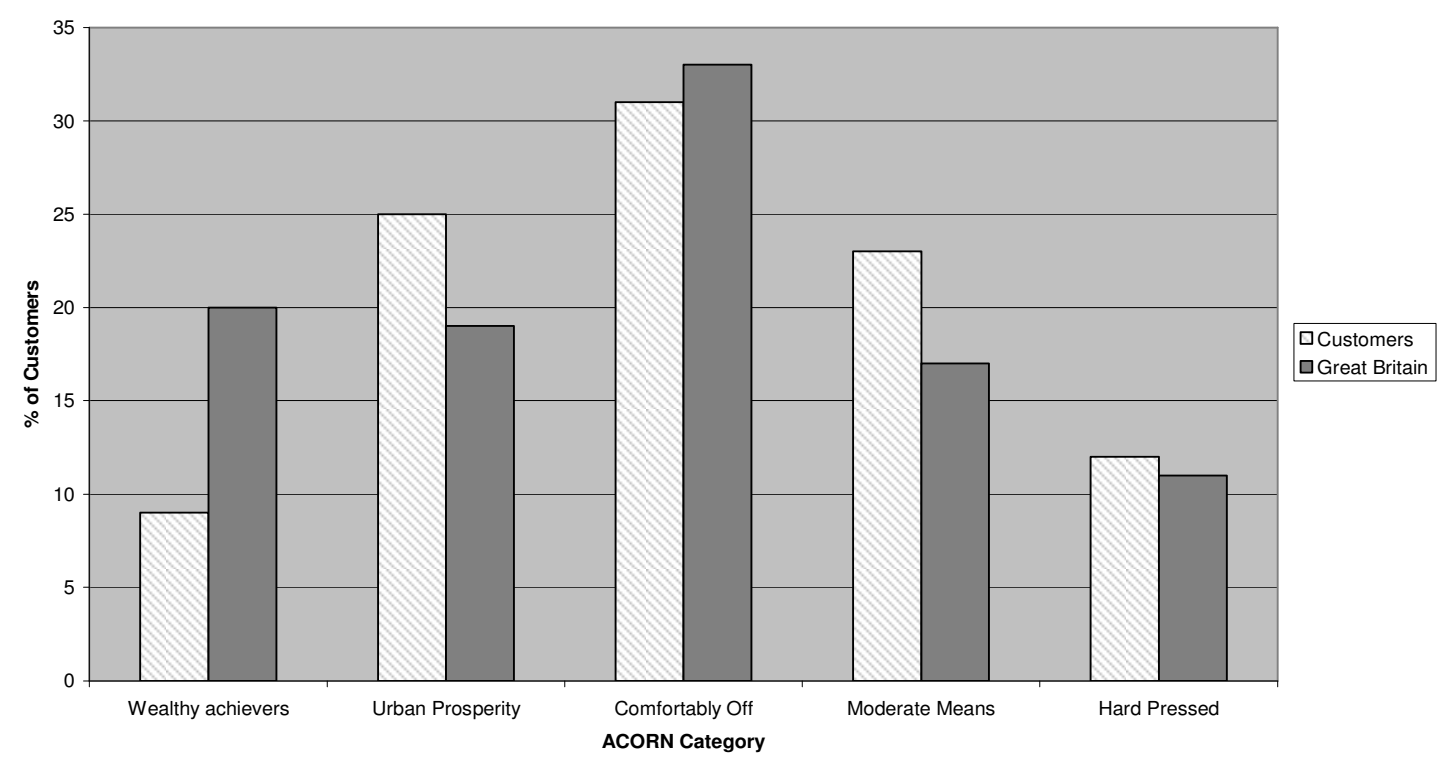

Source: CACI 
Figure 4: ACORN Category profile of product donors

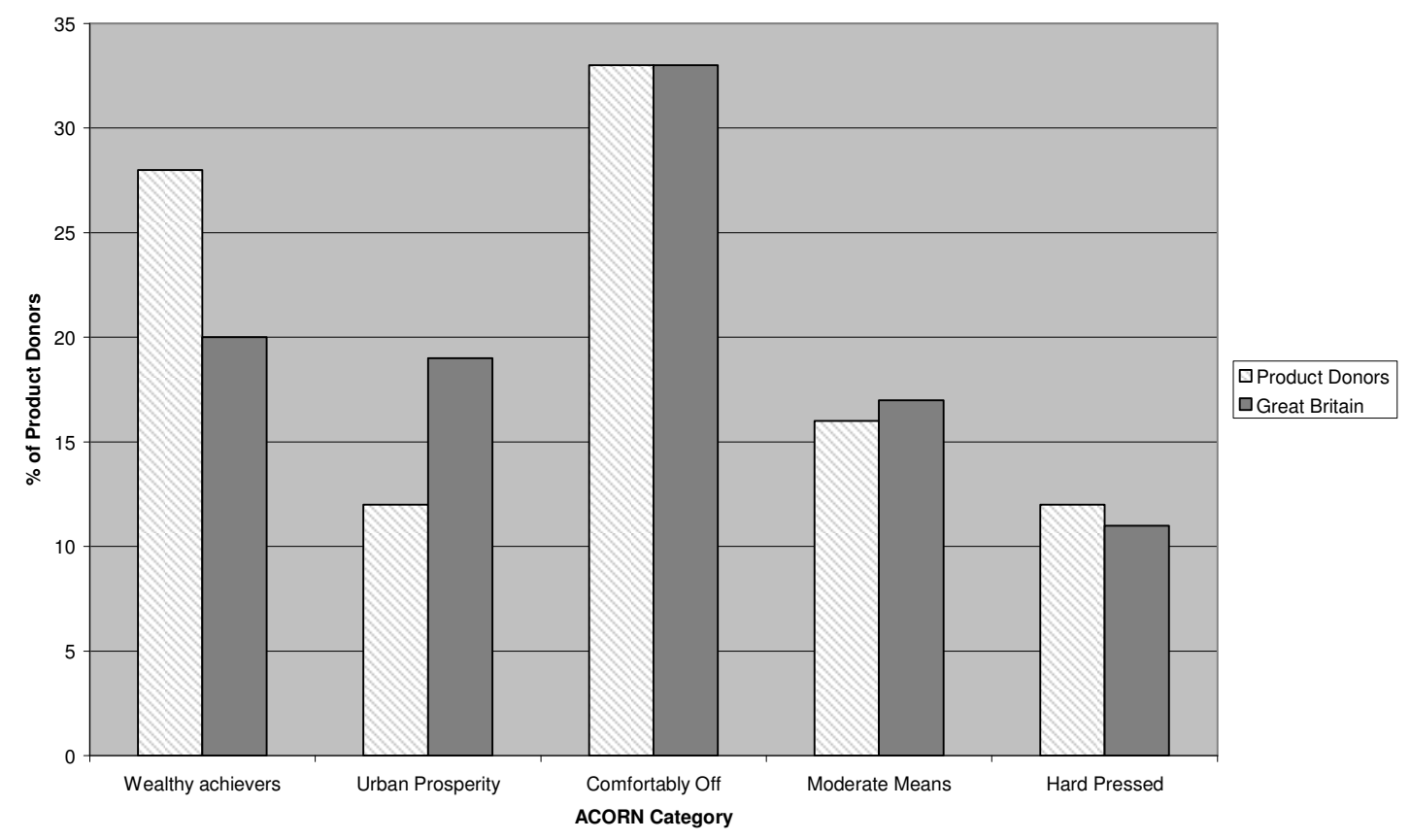

Source: CACI 
Table 1: The profile of Helen \& Douglas shop volunteers

\begin{tabular}{|l|l|l|l|l|l|}
\hline Social Class Grouping & A & B & C1 & C2 & DE \\
\hline Helen \& Douglas Hs. & 23 & 27 & 27 & 4 & 19 \\
Shop Volunteers & & & & & \\
\hline National & 4 & 22 & 29 & 21 & 24 \\
\hline Index & & & & & \\
\hline
\end{tabular}

Source: Helen \& Douglas, 2007.

Notes: Figures shown are percentages. National Average data based upon Office for National Statistics data. 
Figure 5: Housing type map of Oxford

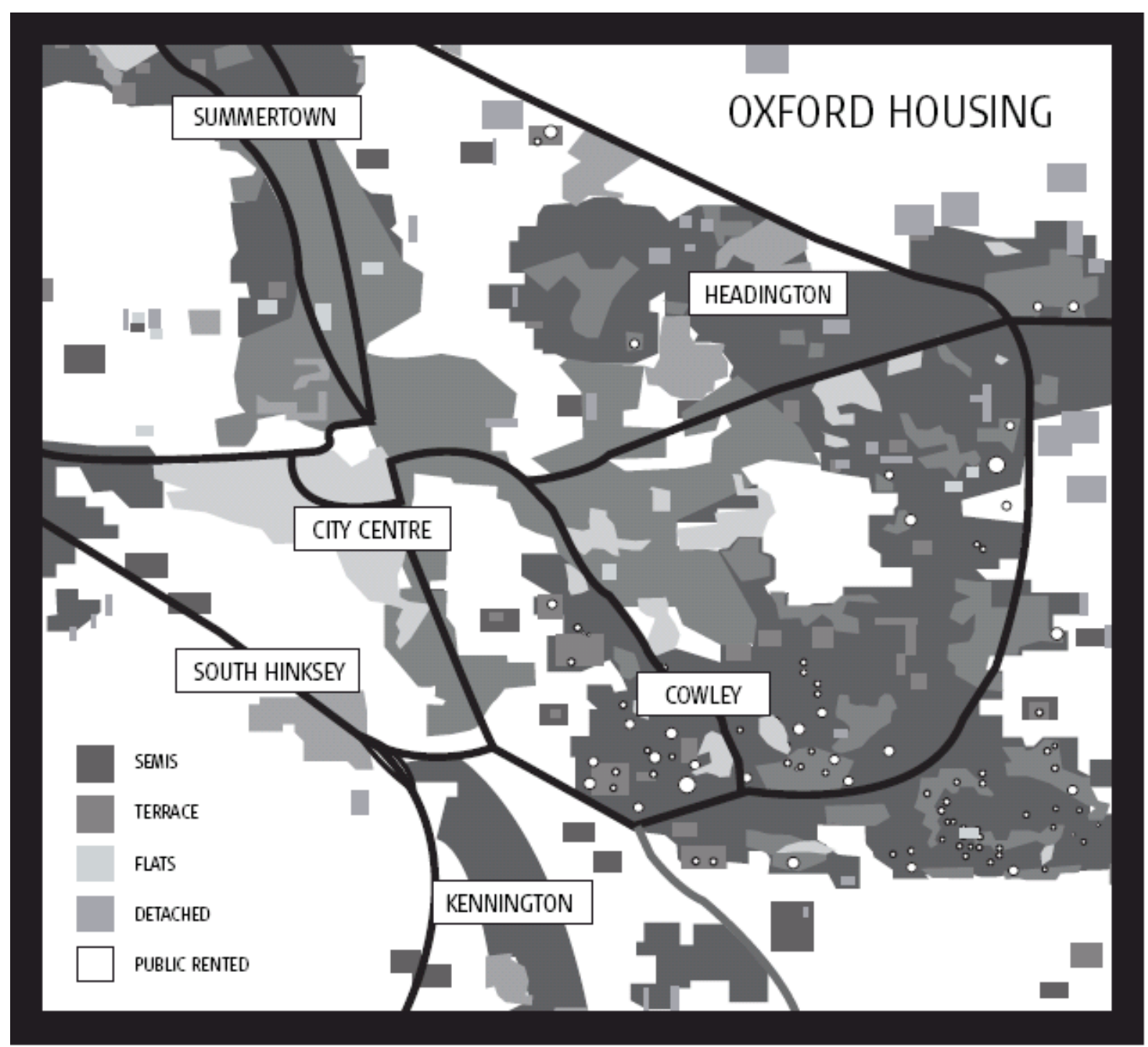




\section{References}

Association of Charity Shops "About Charity Shops - FAQ's" available at http://www.charityshops.org.uk/faqs.html (accessed 16/01/2008).

Barnes, R. (2004) “Cancer Research UK set to open gift shop chain" Marketing, $9^{\text {th }}$ June, p 6.

Bennison, D., Clarke, I. and Pal., J. (1995) "Locational decision-making in retailing: an exploratory framework for analysis", International Review of Retail, Distribution and Consumer Research, Vol 5 No 1, pp. 1-20.

Birkin, M., Clarke, G. and Clarke, M. (2002), Retail Geography and Intelligent Network Planning, John Wiley, Chichester.

Bowlby, S., Breheny, M. and Foot, D. (1984a) "Store location: problems and methods 1: Is locating a viable store becoming more difficult?", Retail and Distribution Management, September/October, pp. 31-33.

Bowlby, S., Breheny, M. and Foot, D. (1984b) "Store location: problems and methods 2: Expanding into new geographical areas", Retail and Distribution Management, November/December, pp. 41-46.

Brito, P. and Malerba, D. (2003) "Mining official data", Intelligent Data Analysis, Vol 7 No 6, pp. 497-500.

Broadbridge, S. and Horne, S. (1994) "Who volunteers for charity retailing and why?", Service Industries Journal, Vol 14 No 4, pp. 421-437.

Broadbridge, S. and Parsons, E. (2003) "UK charity retailing: managing in a newly professionalised sector", Journal of Marketing Management, Vol 19, pp. 729-748.

Byrom, J., Bennison, D., Hernandez, T. and Hooper, P. (2001) "The use of geographical data and information in retail locational planning", Journal of Targeting, Measurement and Analysis for Marketing, Vol 9 No 3, pp. 219-229.

Charity Finance (2007), Charity Shops Survey, 2007, Charity Finance, London.

Clarke, I., Bennison, D. and Pal, J. (1997) "Towards a contemporary perspective on retail location", International Journal of Retail \& Distribution Management, Vol 25 No 2/3, pp. 59-70.

Clarke, I. and Mackaness, W. (2001) "Management 'intuition': An interpretative account of structure and content of decision schemas using cognitive maps", Journal of Management Studies, Vol 38 No 2,pp. 147-172. 
Clarke, I. Mackaness, W. and Ball, B. (2003) "Modelling intuition in Retail Site Assessment MIRSA: making sense of retail location using retailer's intuitive judgments as support for decision-making", International Review of Retail, Distribution and Consumer Research, Vol 13 No 2, pp. 175-193.

Clarkson, R.M., Clarke-Hill, C.M. and Robinson, T. (1996) "UK supermarket location assessment" International Journal of Retail \& Distribution Management, Vol 24 No 6, pp. 22-33.

Davies, R. and Rogers, D. (eds.) (1984), Store Location and Store Assessment Research, John Wiley, Chichester.

Dawson, J.A., Findlay, A.M. and Sparks, L. (1988) "The employment implications of locational decision-making: the case of in-town and out-of-town superstores", International Journal of Retailing, Vol 3 No 2, pp. 35-47.

Freathy, P. and O'Connell, F. (2003) "Relationships within European airport retailing", Service Industries Journal; Vol 23 No 4, pp.114-134.

Hernandez, T. and Bennison, D. (2000) "The art and science of retail location decisions", International Journal of Retail \& Distribution Management, Vol 28 No 8, pp. 357-367.

Hernandez, T., Bennison, D. and Cornelius, S. (1998) "The organisational context of retail location decision-making”, Geojournal, Vol 45 No 4, pp. 295-308.

Hibbert, S., Horne, S. and Tagg, S. (2005) "Charity retailers in competition for merchandise: examining how consumers dispose of used goods", Journal of Business Research, Vol 58, pp. 819-828.

Horne, S. and Broadbridge, A. (1995) "Charity shops: a classification by merchandise mix", International Journal of Retail \& Distribution Management, Vol 23 No 7, pp. 1723.

Horne, S. and Maddrell, A. (2002), Charity Shops: Retailing, Consumption and Society, Routledge, London.

Jardine, A. (2004) “Charitable status hits high street" Marketing, 16 ${ }^{\text {th }}$ June 2004, p. 17.

Kuo, R., Chi, S. and Kao, S. (2002) "A decision support system for selecting convenience store location through integration of fuzzy AHP and artificial neural network", Computers in Industry, Vol 47, pp. 199-214.

Laulajainen, R. (1987), Spatial Strategies in Retailing, Geojournal Library, D. Reidel, Dordrecht. 
Leventhal, B. (2003) "Leveraging the census for customer analysis", Journal of Targeting, Measurement and Analysis for Marketing, Vol 12 No 1, pp. 11-19.

Mendes, A. and Themido, I. (2004) "Multi-outlet retail site location assessment", International Transactions in Operational Research, Vol 1, pp. 1-18.

Murray-West, R. (2006) "Scope to close 50 charity shops as $£ 10 \mathrm{~m}$ loss looms" Telegraph, 13 January available at http://www.telegraph.co.uk/news (accessed 16/01/2006).

Nelson, R. (1958), The Selection of Retail Locations, FW Dodge Corp, New York.

Parsons, E. (2002) "Charity retail: past, present and future", International Journal of Retail \& Distribution Management, Vol 30 No 12, pp. 586-594.

Parsons, E. (2004) "Charity shop managers in the UK: becoming more professional?", Journal of Retailing \& Consumer Services, Vol 11, pp. 259-268.

Parsons, E. and Broadbridge S. (2006) "Job motivation and satisfaction: Unpacking the key factors for charity shop managers" Journal of Retailing and Consumer Services, Vol 13, pp. 121-131.

Pioch, E. and Byrom, J. (2004) "Small independent retail firms and locational decisionmaking: outdoor leisure retailing by the crags", Journal of Small Business and Enterprise Development, Vol 11 No 2, pp. 222-232.

Popkowski Leszczyc, P., Sinha, A. and Timmermans, H. (2000) "Consumer store choice dynamics: an analysis of the competitive market structure for grocery stores", Journal of Retailing, Vol 76 No 3, pp. 323-345.

Quilter, J. (2005) "Save the Children to open 'student' shops"”, Marketing, $19^{\text {th }}$ October, p 5 .

Rogers, D. (1984), "Modern methods of sales forecasting". in Davies, R. and Rogers, D. (eds.), Store Location and Assessment Research, John Wiley, Chichester, pp. 319-332.

Rogers, D. (2005) "Developing a location research methodology", Journal of Targeting, Measurement and Analysis for Marketing, Vol 13 No.3, pp. 201-208.

Sakashita, N. (2000) "An economic analysis of a convenience store location", Urban Studies, Vol 37 No 3, pp. 471-479.

Schneider, K., Johnson, J., Sleeper, B., and Rodgers, W. (1998) "A note on applying retail location models in franchise systems: a view from the trenches", Journal of Consumer Marketing, Vol 15 No 3, pp. 290- 296. 
Sleight, P. (2004) "An introductory review of geodemographic information systems", Journal of Targeting, Measurement and Analysis for Marketing, Vol. 12 No. 4, pp. 379388.

Wood, S. and Browne, S. (2007) "Convenience store location planning and forecasting- a practical research agenda", International Journal of Retail \& Distribution Management, Vol 35 No 4, pp. 233-255.

Wood, S. and Tasker, A. (2008) "The importance of context in store forecasting: the site visit in retail location decision-making", Journal of Targeting, Measurement and Analysis for Marketing, in press.

Wrigley, N. and Lowe, M. (eds.) (1996), Retailing Consumption and Capital: Towards the New Retail Geography, Longman, London. 